\title{
Streptococcus pyogenes
}

National Cancer Institute

\section{Source}

National Cancer Institute. Streptococcus pyogenes. NCI Thesaurus. Code C86803.

A species of facultatively anaerobic, Gram positive, cocci shaped bacteria in the phylum Firmicutes. This species is beta hemolytic, Lancefield group A, pyrrolidonylarylamidase, and arg inine deaminase positive and catalase negative. It can ferment salicin, rhamnose, and trehalose but not sorbitol, or ribose. S. pyogenes is found on normal human skin but can act as a pathogen causing streptococcal pharyngitis, acute rheumatic fever, scarlet fever, skin infections, acute glomerulonephritis and necrotizing fasciitis. 